\title{
NAMA:NURUL FITRIYAH
}

\section{NIM:10200120142}

\section{KELAS:HTN D}

\section{RESUME YANG BERKAITAN DENGAN PARTAI POLITIK DAN PEMILIHAN UMUM}

\section{A.SEJARAH PERKEMBANGAN PARTAI POLITIK}

Partai politik pertama-tama lahir dinegara eropa barat.Dengan meluaskan gagasan bahwa rakyat merupakan faktor yang perlu diperhitungkan serta diikutsertakan dalam proses politik, maka partai polituk telah lahir secara spontan dan berkembang menjadi penghubung antara rakyat di satu pihak dan pemerintahan di pihak lain.

Pada awal perkembangannya,pada akhir dekade 18 -an di negara-negara barat seperti inggris dan prancis,kegiatan politik dipusatkan pada kelompok-kelompok politik dalam parlamen.kegiatan ini mula-mula bersifat elitis dan aristokratis, mempertahankan kepentingan kaum bangsawan terhadap tuntutan-tuntutan raja.

Dengan meluasnya hak pilih,kegiatan politik juga berkembang diluar parlemen dengan terbentuknya panitia-panitia pemilihan yang mengantur pengumpulan suara pada pengdukungnya menjelang masa pemilihan umum (kadang-kadang dinamakan caucus party). Oleh karena dirasa perlu memperoleh dukungan dari berbgai golongan masyarakat, kelompokkelompok politik di parlemen lambat lau juga berusaha mengembangkan oeganisasi massa. Maka pada akhir abad ke-19 lahirlah partai politik, yang pada masa selanjutnya berkembang menjadi penghubung (link) antara rakyat di satu pihak dan pemerintah dipihak lain.

\section{B.DEFINISI PARTAI POLITIK}

Partai politik berangkat dari anggapan bahwa dengan membentuk wadah organisasi mereka bisa menyatukan orang-orang yang mempunyai pikiran serupa sehingga pikiran dari orientasi mereka bisa dikonsolidasikan. Dengan begitu pengaruh mereka bisaa lebih besar dalam pembuatan dan pelaksanaan keputusan.

Secara umum dapat dikatakan bahwa partai politik adalah suatu kelompok terorganisir yang anggota-anggotanya mempunyai orientasi, nilai-nilai, dan cita-cita yang sama. Tujuan kelompok ini ialah untuk memperoleh kekuasaan politk dan merebut kedudukan politik-(biasanya) dengan cara konstitusional-untuk melaksanakan programnya.Banyak sekali definisi mengenai partai politik yang dibuat oleh para sarjana. Dibagian ini dipaparkan beberapa contoh definisi yang dibuat para ahli ilmu klasik dan kontenporer.

Carl J. Friedich menuliskan sebagai berikut:

Partai politik adalah sekelompok manusia yang terorganisir sacara stabil dengan tujuan merebut atau mempertahankan penguasaan terhadap pemerintah bagi pimpinan partainya dan 
berdasarkan penguasaan ini, memberikan kepada anggota partainya kemanfaatan yang bersifat idiil serta materil.

Sigmund Neuman dalam buku karyanya, Modern political parties, mengemukakan definisi sebagai berikut:

Partai politik adalah organisasi dari aktivis-aktivis politik yang berusaha untuk manguasai kekuasaan pemerintah serta merebut dukungan rakyat melalui persaingan dengan suatu golongan atau golongan-golongan lain yang mempunyai pandangan yang berbeda.

\section{C.FUNGSI PARTAI POLITIK}

- Fungsi di Negara Demokrasi

* Sebagai Sarana Komunikasi Politik

Di masyarakat modern yang luas dan kompleks, banyak ragam pendapat dan aspirasi yang berkembang. Pendapat atau aspirasi seseorang atau suatu kelompok akan hilang tak berbekas seperti suara di padang pasir, apabila tidak ditampung dan digabung dengan pendapat dan aspirasi orang lain yamg sedana. Proses ini dinamakan penggabungan kepentingan.(interest aggregetion). Sesudah digabungkan, pendapat dan aspirasi tai diolah dan dirumuskan dalam bentuk yang lebih teratur. Proses ini dinamakan perumusan kepentingan(interest articulation)

* Sebagai Sarana Sosialisasi Politik Dalam ilmu politik sosialisasi politik diartikan sebagai suatu proses yang melaluinya seseorang memperoleh sikap dan orientasi terhadap fenomena politik, yang umumnya berlaku dalam masyarakat dimana ia berada. la adalah bagian dari proses yang menentukansikap politik seseorang. Misalnya mengenai nasionalisme, kelas sosial, suku bangsa, ideologi, hak dan kewajiban.

Dimensi lain dari sosialisasi politik adalah sebagai proses yang melaluinya masyarakat menyampaikan " budaya politik" yaitu norma-norma dan nilai nilai, dari satu generasi ke generasi berikutnya. Dengan demikian sosialisasi politik merupakan faktor penting dalam terbentuknya budaya politik (political culture) suatu bangsa.

Suatu definisi yang dirumuskan oleh seorang ahli sosiologi politik M.Rush (1992) Sosialisasi politik adalah proses yang melaluinya orang dalam masyarakat tertentu belajar mengenali sistem politiknya. Proses ini sedikit banyak menentukan persepsi dan reaksi mereka fenomena politik.

* Sebagai Sarana Rekrutmen Politik Fungsi ini berkaitan erat dengan masalah seleksi kepemimpinan, baik kepemimpinan internal partai maupun kepemimpinan nasional yang lebih luas. Untuk kepentingan internalnya, setiap partai butuh kader kader yang berkualitas, karena hanya dengan kader yang demikian ia dapat menjadi partai mempunyai kesempatan lebih besar untuk mengembangkan diri. Dengan mempunyai kaderkader yang baik, partai tidak akan sulit menentukan pemimpinnya sendiri dan mempunyai peluang untuk mengajukan calon untuk masuk kebursa kepemimpinan nasional. 
* Sebagai Sarana Pengatur Konflik(Conflict Management)

Potensi konflik selalu ada disetiap masyarakat, apalagi di masyarakat bersifat heterogen, apakah dari segi etnis (suku bangsa), sosial ekonomi, ataupun agama. Setiap perbedaan tersebut menyimpan konflik. Apabila keanekaragaman itu terjadi di negara yang menganut paham demokrasi, persaingan dan perbedaan pendapat dianggap hal yang wajar dan mendapat tempat. Akan tetapi didalam negara yang heterogen sifatnya, potensi pertentangan lebih besar dan dengan mudah mengundang konflik.

Disini peran partai politik diperlukan untuk membantu mengatasinya, atau sekurang-kurangnya dapat diatur sedemikian rupa sehingga akibat negatifnya dapat ditekan sedemikian mungkin. Elite partai dapat menumbuhkan pengertian diantara mereka dan bersamaan itu juga meyakinkan pendukungnya.

* Fungsi Dinegara Otoriter Hal-hal yang dijelaskan dibagian terdahulu adalah fungsi-fungsi partai menurut pandangan yang berkembang dinegara yang menganut paham demokrasi. Menurut paham komunis, sifat dan tujuan partai politik bergantung pada situasi apakah partai komunis berkuasa dinegara dimana ia berada atau tidak. Dinegara dimana partai komunis tidak berkuasa, partai-partai politik lain dianggap sebagai mewakili kepentingan kelas tertentu yang tidak dapat bekerja untuk kepentingan umum. Dalam situasi seperti itu, partai komunis akan mempergunakan setiap kesempatan dan fasilitas yang tersedia (seperti yang banyak terdapat dinegaranegara demokrasi) untuk mencari dukungan seluas-luasnya, misalnya dengan jalan memupuk rasa tidak puas dikalangan rakyat. Partai komunis bertujuan mencapai kedudukan kekuasaan yang dapat dijadikan batu loncatan guna menguasai partai politik yang ada dan menghancurkan sistem politik yang demokratis. Maka dari itu, partai ini menjadi paling efektif dinegara yang pemerintahannya lebah dan rakyatnya kurang bersatu.

Akibat karakternya yang demikian, partai komunis sering dicurigai dan dibeberapa negara bahkan dilarang. Akan tetapi tindakan semacam itu juga ada bahayanya. Sebab dalam keadaan itu partai akan bergerak dibawah tanah, sehingga justru sukar diawasi. Apabila tidak menentukan jalan untuk merebut kekuasaan, partai akan mencoba mencapai tujuannya melalui kerja sama dengan partai-partai lain dengan mendirikan front Rakyat atau Front Nasional (popular front tactics) Berbeda halnya apabila partai komunis berkuasa. Di sini partai komunis mempunyai kedudukan monopolistis, dan kebebasan bersaing ditiadakan. Dapat saja ia menentukan dirinya sebagai partai tunggal atau sekurang-kurangnya sebagai partai yang paling dominan, seperti yang terjadi di Uni Soviet, China, dan negara-negara komunis Eropa Timur.

Tujuan partai komunis adalah membawa masyarakat kerah tercapainya masyarakat yang modern dengan ideologi komunis, dan partai berfungsi sebagai " pelopor revolusioner " untuk mencapai tujuan itu partai komunis Uni Soviet yang berkuasa dari tahun 1917-1991 merupakan partai seperti itu. Partai komunis juga melaksanakan beberapa fungsi, tetapi pelaksanaannya sangat berbeda dengan yang ada dinegara-negara demokrasi. Misalnya, dalam rangka berfungsi sebagai sarana komunikasi politik partai menyalurkan informasi 
untuk mengindoktrinasikan masyarakat dengan informasi yang menunjang usaha pimpinan partai. Arus informasi lebih bersifat dari atas ke bawah, daripada arus dua arah. mengutamakan orang yang mempunyai kemampuan untuk megabdi kepada partai, yang menguasai ideologi marxisme-Leninisme, dan yang kelak mampu menduduki kedudukan pimpinan untuk mengawasi kegiatan dari berbagai aspek kehidupan.

\section{SISTEM PEMILIHAN UMUM}

* Sistem Pemilihan Umum

Di kebanyakan negara demokrasi, pemilihan umum dianggap lambang sekaligus tolak ukur, dari demokrasi itu. Hasil pemilihan umum yang diselenggarakan dalam suasana keterbukaan dengan kebebasan berpendapat dan kebebasan bersyerikat, dianggap mencerminkan dengan agak akurat partisipasi serta aspirasi masyarakat. Sekaligus demikian, disadari bahwa pemilihan umum tidak merupakan satu-satunya tolak ukur dan perlu dilengkapi dengan pengukuran beberapa kegiatan lain yang lebih bersifat berkesinambungan, seperti partisipasi dalam kegiatan partai, lobbyng, dan sebagainya.

Dibanyak negara dunia ketiga beberapa kebebasan seperti yang dikenal didunia barat kurang diindahkan atau sekurang-kurangnya diberi tafsiran yang berbeda. Dalam situasi semacam ini, setiap analisis mengenai hasil pemilihan umum harus memperhitungkan faktor kurang bebasan itu serta kemungkinan adanya faktor mobilisasi yang sedikit banyak mengandung unsur paksaan.

Dalam ilmu politik dikenal bermacam-macam sistem pemilihan umum dengan berbagai pariasinya, akan tetapi umumnya berkisar pada dua prinsip pokok yaitu :

a. Single Member Constituency ( satu daerah pemilihan memiliki satu wakil : biasanya disebut sistem distrik).

b. Mult-member Constituency ( satu daerah pemilihan memilih beberapa wakil: biasanya dinamakan dengan sistem perwakilan berimbang atau sistem proposional)

Dalam sistem distrik, satu wilayah kecil (yaitu pemilihan) memilih satu wakil tunggal (Single Member Constituency) atas dasar pruralitas ( Suara Terbanyak ). Dalam sistem proposional, satu wilayah besar (yaitu daerah pemilihan) memiih beberapa wakil (Mult-Member Constituency) perbedaan pokok antara kedua sistem ini adalah bahwa cara menghitung perolehan suara dapat menghasilkan perbedaan dalam komposisi perwakilan dalam parlemen bagi masing masing partai politik.

Sistem distrik merupakan sistem pemilihan yang paling tua dan didasarkan atas kesatuan geografis. Setiap kesatuan geografis (Yang biasanya disebut "distrik" karena kecilnya daerah yang tercakup) memperoleh satu kursi dalam parlemen. Untuk keperluan itu negara dibagi dalam sejumlah besar distrik pemilihan (kecil) yang kira-kira sama jumlah penduduknya. (jumlah distrik berbeda dari satu negara kekenegara lain, misalnya di inggris jumlah penduduk kira-kira 50.000, di Amerika kira-kira 500.000 dan di India lebih dari satu juta). 
Dalam sistem distrik, satu distrik menjadi bagian dari suatu wilayah, satu distrik hanya berhak atas satu kursi, dan kontestan yang memperoleh suara terbanyak menjadi pemenang tunggal. Hal ini dinamakan the first past the post (FPTP). Pemenang tunggal meraih kursi itu. Hal ini terjadi sekaligus selisih suara dengan partai lain hanya kecil saja. Suara yang tadinya mendukung kontestan lain dianggap hilang (wasted) dan tidak dapat membantu partainya untuk menambah jumlah suara partai di distrik lain. Dalam sistem proposional, satu wilayah dianggap sebagai satu kesatuan, dan dalam wilayah itu jumlah kursi dibagi sesuai jumlah suara yang diperoleh oleh para kontestan, secara nasional tanpa distribusi suara itu.

Sebagai contoh hipotesis, bayangkanlah adanya suatu wilayah dengan 100.000 penduduk dimana tiga partai bersaing memperebutkan 10 kursi diparlemen. Wilayah itu terdiri atas sepuluh distrik. Seandainya dalam wilayah dipakai sistem distrik berhak atas satu kursi dari jumlah total 10 kursi yang diperebutkan dengan jumlah total 10 kursi. Seandanya dipakai sistem proposional wilayah dianggap sebagai satu kesatuan yang sebagai keseluruhan berhak atas 10 kursi.

Misalnya dalam satu distrik ada tiga calon. Calon a beserta partainya memperoleh $60 \%$ suara, calon b mendapatkan $30 \%$ suara, dan calon 3 mendapatkan $10 \%$ suara. Pemenang calon partai a memperoleh satu kursi sedangkan 30\% jumlah suara dari calon b dan $10 \%$ dari calon c dianggap hilang.

Seandainya dalam wilayah tersebut dipakai sistem proposional wilayah itu yang bisa berbentuk kesatuan administratif misalnya provinsi dianggap sebagai kesatuan yang keseluruhannya berhak atas sepuluh kursi. Jumlah suara yang diperoleh secara nasional oleh setiap partai menentukan jumlah kursinya parlemen, artinya persentasi perolehan suara secara nasional dan setiap partai sama dengan persentase perolehan kursi dalam parlemen. Misalnya partai a memperoleh $60 \%$ suara dalam wilayah itu, akan memperoleh enam kursi dalam parlemen demikian pula partai b yang memperoleh 30\% suara akan mendapatkan tiga kursi, dan partai c dengan 10\% suara mendapatkan satu kursi.

Sistem distrik sering dipakai di negara yang mempunyai sistem dwi partai seperti inggris serta bekas jajahannya seperti india dan malaysia dan amerika. Sistem proposional sering diselanggarakan dalam negara dengan banyak partai seperti bergia, swedia, italia, negeri belanda, dan indonesia.

Disamping itu, ada ciri khas melekat pada sistem distrik yaitu bahwa pelaksanaan sistem distrik mengakibatkan " distorsi” atau kesengajaan antara jumlah suara yang diperoleh suatu partai secara nasional dan jumlah kursi yang diperoleh partai tersebut. Akibat dari distorsi menguntungkan partai besar dan merugikan partai kecil hal ini disebabkan banyak suara dari partai kecil bisa dinyatakan hilang atau wasted yaitu lantaran tidak berhasil menjadi juara pertama disuatu distrik. Keadaan ini akan sangat berpengaruh dalam masyarakat yang pluralis, dengan banyaknya kelompok minoritas, baik agama maupun etnis. 
Sebagai contoh, pemilihan umum 1992 partai konservatif inggris yang dipimpin jhon major hanya memperoleh $41,9 \%$ dari jumlah total suara. Akan tetapi karna berhasil menang dibanyak distrik sebagai pemenang tunggal, (651) dalam parlemen, dan dapat membentuk kabinet tanpa koalis. Sebaliknya partai ketiga, partai liberar demokrat memperoleh dukungan yang cukup luas dalam banyak distrik, tetapi tidak cukup terkonsentrasi untuk menjadi pemenang tunggal dalam distrik yang bersangkutan. Tidak mengherankan bahwa partai liberal demokrasi menuntut agar sistem distrik diganti dengan sistem proporsional karena dianggap tidak adil dan tidak mengherankan pula bahwa partai-partai besar mengabaikan imbauan ini.

\section{E. KEUNTUNGAN DAN KELEMAHAN KEDUA SISTEM}

Keuntungan Sistem Distrik

1. Sistem ini lebih mendorong ke arah integrasi partai-partai politik karena kursi yang diperebutkan dalam setiap distrik hanyasatu. Hal ini akan mendorong partai-partai untuk menyisihkan perbedaan-perbedaan yang ada dan mengadakan kerja sama, sekurang-kurangnya menjelang pemilihan umum, antara lain melalui stembus accooed.

2. Fregmentasi partai dan kecenderungan membentuk partai baru dapat dibendung, malahan sistem ini bisa mendorong ke arah penyederhanakan partai secara alami dan tanpa paksaan.

Kelemahan Sistem Distrik

1. Sistem ini kurang memerhatikan kepentingan partai-partai kecil dan golongan-golongan minoritas, apalagi jika golongan-golongan ini terpencar dalam berbagai berbagai distrik.

PROF. MIRIAM BUDIARDJO

JUDUL BUKU : DASAR - DASAR ILMU POLITIK

PENERBIT PT GRANDMEDIA PUSTAKA UTAMA, JAKARTA 2007

546 HALAMAN 